\title{
ASSESSING CHANGES IN Cd PHYTOAVAILABILITY TO TOMATO IN AMENDED CALCAREOUS SOILS
}

\author{
MORAL $^{\mathrm{a}^{*}}$ R, CORTÉS ${ }^{\mathrm{b}}$ A, GOMEZ ${ }^{\mathrm{a}}$ I, AND MATAIX BENEYTO ${ }^{\mathrm{a}} \mathrm{J}$ \\ ${ }^{a}$ Dpt. Agroquimica y Medio Ambiente. Universidad Miguel Hernández. EPS-Orihuela, \\ E-03312 Orihuela-Alicante. Spain \\ ${ }^{b}$ SD Edafologia. Facultad de Farmacia. Universidad de Barcelona. Avda. Joan XXIII, s/n. \\ 08028 Barcelona. Spain
}

\begin{abstract}
A plot study was conducted to assess changes in $\mathrm{Cd}$ phytoavailability to a tomato cultivar in an agricultural soil in Southeastern Spain amended in two different ways (A and B), under controlled conditions. The experimental soil corresponded to a fine-loamy carbonatic thermic Calcidic Haploxeroll (Soil Survey Staff, 1998).

A) Soil was amended with a single application of sewage sludge from a municipal source that had a total $\mathrm{Cd}$ concentration of $0.5 \mathrm{mg} \mathrm{kg}^{-1}$ at a rate that represented a final average concentration in the mixture of soil and sludge of less than $50 \mu \mathrm{g} \mathrm{Cd} \mathrm{kg}^{-1}$.

B) The amendment consisted of the addition of a mineral fertiliser with the same amount of NPK as in the sewage sludge application. The final levels of $\mathrm{Cd}$ were supposed to be negligible. A plot series without amendments was also performed (C).

DTPA plus triethanolamine, and ammonium acetate extractable fractions in soils were analysed for all the plots. The time-dependent $\mathrm{Cd}$ accumulation in different parts of the tomato plants was studied by means of a Cd salt treatment. For each block (A, B, and C) four
\end{abstract}

Corresponding author:

R. Moral; Dpt. Agroquímica y Medio Ambiente. Universidad Miguel Hernández. EPS-Orihuela, E-03312 Orihuela-Alicante (Spain)

Phone: 966749652 Fax:966749655_E-mail: raul.moral@umh.es 
levels of $\mathrm{Cd}\left(0,3,30,100 \mathrm{mg} \mathrm{kg}^{-1}\right)$ were added as $\mathrm{CdCl}_{2}$. There was a significant increase in plant Cd after the initial cropping.

Tomato stems, leaves and fruits were analysed separately for Cd determination. Differential Cd distribution and accumulation in tomato parts was detected.

Keywords: cadmium bioavailability, cadmium bioaccumulation, cadmium phytoavailability, sewage sludge, calcareous soil, tomato.

\section{INTRODUCTION}

During the 90s, there has been in the Mediterranean coastal areas an increasing interest in reuse of organic by-products either for agricultural purposes or for degraded land restoration (mostly at mining areas). Among those waste materials, sludges from the increasing number of wastewater treatment plants has biend the main interest.

However, one of the main problems that condition sludge use is the potential effect derived from the presence of heavy metals. In the same way, uncontrolled mineral fertiliser application could be another important input for such metal contaminants of agricultural soils as cadmium occurs in ores used in the production of $\mathrm{P}$ fertilizers.

Among other metals cadmium is nowadays of great concern. There is sufficient evidence in humans for the carcinogenicity of cadmium and cadmium compounds, and for genotoxic effects of ionic forms in a variety of types of eukaryotic cells, including human ones. Cadmium enters the body mainly by inhalation and by ingestion. Intestinal absorption is influenced by dietary factors, and increases with dietary cadmium concentration.

$\mathrm{Cd}$ is an element that is neither regulated nor essential for plants. Cd content in agricultural soils is generally low, about 0.1 to $5 \mu \mathrm{g} / \mathrm{g}$. However there are estimations that 
foresee a $6 \%$ yearly increase due to man's action (Tjell et al., 1981). Since the early century, Cd has been produced and used in a variety of applications in alloys and in different compounds which explains its widespread distribution.

The phytoavailability of Cd largely depends on its speciation in soils. Distribution of Cd forms in soils is extremely variable. Chang et al. (1984) found that in soils treated with sewage sludge the most significant fractions that could explain chemical changes were the carbonate and the organic fractions.

Bioavailable forms are crucial in assessing the toxic impact in a soil-plant system (Shuman, 1991). Plant uptake is closely related to element concentration in soil solution; with the exchangeable fraction (Gerritse et al., 1983). For this reason, there are a lot of methods and extraction solutions for metal determination in soils (Beckett, 1989) and much work has been done in order to establish a correlation between plant sorption and metal concentrations in soils (Legret et al., 1988; He and Singh, 1993; Cabral and Lefebvre, 1998). Different factors have to be considered when considering soil-plant transfer. The transport of $\mathrm{Cd}$ in the soil-water systems seems to be a fast process. Soil sorption capacity for $\mathrm{Cd}$ has been found to be correlated with $\mathrm{pH}$ at the stable adsorption stage $(\mathrm{ZPC}<\mathrm{pH}<6.0)$. At $\mathrm{pH}>6.0$ strong adsorption is always observed. The bioavailability of soil sorbed $\mathrm{Cd}$ increased with $\mathrm{pH}$ when $\mathrm{pH}<6$, while it decreased with $\mathrm{pH}$ when $\mathrm{pH}>6$. At $\mathrm{pH} 7.5$, large percentages of $\mathrm{Cd}$ remain bound, so reducing its toxicity (Liao et al., 1999). Calcite and dolomite in silt and clay fractions seem to be responsible for strong associations with cadmium (Vigil de la Villa et al., 1997).

Uptake of metals by plants growing in sewage sludge-amended soils frequently exhibits a plateau response at high sludge loading rates associated with high total concentrations of metals in the soil. This type of response has generally been attributed to decrease of metal bioavailability by increased sorption at sites provided by the sludge constituents at the high sludge loading rates (Logan, 1997). Metal transport from roots to 
shoots is a long distance transport controlled by a certain number of physiological processes including metal unloading into root xylem cells, long distance transport within the xylem to the shoots, and metal reabsorption from the xylem stream by leaf mesophyll cells (Raskin and Ensley, 2000).

In the present work two simplified methods for studying metal mobility and phytoavailability in soils are proposed, and their usefulness in establishing correlations with cadmium concentrations in tomato plants, at fixed soil moisture content, is checked. The final aims were to evaluate the transfer of $\mathrm{Cd}$ from agricultural soils to cultivated plants, $\mathrm{Cd}$ concentrations in edible parts, and factors affecting cadmium phytoavailability.

\section{METHODS}

A number (144) of pots (20 kg capacity) were prepared with the top layer $(0-30 \mathrm{~cm})$ of a calcareous soil (Calcidic Haploxeroll, according S.S.S. 1998). Three treatment blocks were carried out (addition of sewage sludge (SS), inorganic equivalent fertilisation (IN), and no fertilisation $\mathrm{W})$ and for each block four levels of $\mathrm{Cd}\left(0,3,30,100 \mathrm{mg} \mathrm{kg}^{-1}\right)$ were added as $\mathrm{CdCl}_{2}$. One tomato plant was planted in each pot. All pots were located in greenhouse under controlled climatic conditions (temperature, day leng, cuando se cultivaroin).

Soil and sewage sludge analyses were performed according to conventional methods (Navarro-Pedreño et al., 1996) and results are shown in Table 1.

The amount of sludge added to the soil $\left(30 \mathrm{Ton} \mathrm{ha}^{-1}\right)$ was calculated according to standard requirements of tomato fertilisation $\left(300 \mathrm{~N}, 200 \mathrm{P}_{2} \mathrm{O}_{5}\right.$ and $\left.300 \mathrm{~K}_{2} \mathrm{O} \mathrm{kg} \mathrm{ha}{ }^{-1}\right)$. The N content of sludge was equivalent to an actual addition of $\mathrm{N}$ of $300 \mathrm{~kg} \mathrm{ha}^{-1}$ following the recommendation of Cogger et al., (1987).

The inorganic NPK fertilisation, equivalent to the dose applied with the sewage sludge, was done using monoammonium phosphate, potassium nitrate and ammonium nitrate. 
Bioavailable $\mathrm{Cd}$ at pot soils was obtained by two different extraction procedures: a) dissolution in $0,005 \mathrm{M}$ DTPA, $0,01 \mathrm{~N} \mathrm{CaCl}_{2}$ and $0,1 \mathrm{~N}$ Triethanolamine at $\mathrm{pH}$. The socalled Linsay-Norwell solution is supposed to extract available metals, organic matter-bound metals, but is also able to dissolve some precipitated forms (Schalscha et al., 1980).

b) ammonium acetate (1N) at pH 7 (Knudsen et al., 1982), that extracts exchangeable forms (Förstner et al., 1981; Iyengar et al., 1981; Soon and Baltes, 1982).

In all cases, extracted Cd was measured by atomic absorption spectroscopy (AAS Perkin Elmer 2100-graphite furnace HGA 700). Each analytic determination was carried out in quadruplicate and average values are given in Results and Discussion.

Stems, leaves and fruits were analysed separately. Plant samples were obtained at the beginning of the flowering period (S1), at the beginning of ripening stage of fruits (S2), and at the full production stage (S3). Plant tissue (previously cleaned with water) was dried at $60^{\circ}$ $\mathrm{C}$ in a forced-air oven. Dried samples were mineralised by microwave acid digestion, using $\mathrm{HNO}_{3} / \mathrm{H}_{2} \mathrm{O}_{2}$ in ratio 4:1 (v/v) (White and Douthit, 1985; Kalra et al., 1988; Moral et al., 1996). Cadmium content was determined using atomic absorption spectrophotometry (AAS Perkin Elmer 2100-graphite furnace HGA 700), with a detection limit about $25 \mu \mathrm{g} \mathrm{Cd}$.

A statistical ANOVA F test was applied to the results and double way ANOVA test was used considering the combined effect of the fertilisation $(\mathrm{F})$ and the Cd pollution $(\mathrm{P})$.

\section{RESULTS AND DISCUSSION}

\section{$\underline{\text { Soil distribution of cadmium }}$}

Ammonium acetate- and DTPA-extractable $\mathrm{Cd}$ increased with total soil $\mathrm{Cd}$. The contents of Cd for each soil extract are shown in Table 2. A higher extractability of Cd with DTPA was observed in all experiments. 
Cd extracted by ammonium acetate was very similar in organic- and inorganicfertilised soils and in the non-fertilised ones, except for the highest Cd soil contents (100 ppm). Very little variation of ammonium acetate $\mathrm{Cd}$ extractability was observed in the experiments with 3 and $30 \mathrm{mg} \mathrm{Cd} / \mathrm{kg}$ treatments in all the fertiliser additions. This fact could indicate that the pollutant extracted from soil solution by plants is replaced quickly by the exchange mechanisms of the soil and/or by slight dissolution of some precipitated forms because of the ammonium acetate $\mathrm{pH}$.

The interaction between the type of fertilisation and Cd extracted was higher with DTPA extract, with significant differences between fertilisation blocks and vegetative periods.

DTPA cadmium extractability decreased with time for low $\mathrm{Cd}$ levels in the same treatments. Considering that the DTPA extract also includes the Cd fraction associated with the organic matter, we can conclude that $\mathrm{Cd}$ sorbed to organic compounds could be progressively readsorbed by plants in calcareous soils.

A different behaviour was detected for the highest treatment of Cd (100 ppm), with a significant increase of Cd-DTPA or a plateau formation with time. The highest increment of CdDTPA was detected in the sewage sludge amended soils, richer than others in organic compounds.

This evolution can be explained by the initial formation of insoluble compounds of $\mathrm{Cd}$, which can be transferred gradually to the active surfaces of the soil, probably because of soil $\mathrm{pH}$ reduction, and by the lability of the organic complexes of this metal, which can enhance their bioavailability (Hanafi and Salwa, 1998). 


\section{$\underline{\text { Plant cadmium }}$}

As we can see in Table 3, leaf tissue is the vegetative aerial part that has the highest concentration of $\mathrm{Cd}$, for all the fertilisation and pollutant treatments. This behaviour has been reported by other researchers with tomato plants (Wolterbeek et al, 1988; Moral et al, 1994). Cd content in stem and branches did not vary significantly with time of exposure for different treatments at low soil $\mathrm{Cd}$ concentrations. Fruit $\mathrm{Cd}$ accumulation was low compared with the other parts analysed, and apparently under less influence of the different treatments. Cd presence in tomato fruit was one order of magnitude lower that Cd in leaves. Kim et al (1988) found that the ratio between leaf and fruit concentration of $\mathrm{Cd}$ in tomato plants grown in polluted soils was about 30-60, depending on the type of soil. Sewage sludge amended soils showed a higher presence of $\mathrm{Cd}$ in the aerial part of the tomato plants compared to inorganic fertilisation. However, in similar experiments with several types of plant, Logan and Miller (1985) reported no statistical differences between organic and inorganic fertilisation on Cd in the plant. Cd accumulations in stem, leaves and fruit seem to be affected directly by the presence of $\mathrm{Cd}$ in the soils and by the fertilising treatments, organic fertilisation causing the highest concentrations, especially with increasing time of contact.

There was a $\mathrm{Cd}$ accumulation in fruit close to $9 \mathrm{mg} \mathrm{kg}^{-1} \mathrm{~d} . \mathrm{w}$. in plants grown in the sewage sludge amended soils with the highest treatment of Cd (100 ppm); this fact indicates a very high transfer rate from soil to fruit. A fruit accumulation coefficient (fruit/soil Cd concentration quotient) was found close to $1 / 10$.

\section{Effects of $\mathrm{Cd}$ on biomass production and plant bioavailability}

The production of aerial biomass was significantly higher in the fertiliser treatments compared to the control, but no statistical differences between organic and inorganic 
fertilisation. The yield of tomato plants followed the sequence: control<inorganic fertilisation<organic fertilisation.

The $\mathrm{Cd}$ added to soil seemed to reduce the biomass production in some fertilizing systems, but this effect was low and not correlated with the increasing dose of pollutant. A very high negative effect of $\mathrm{Cd}$ was observed on yield in the non-fertilised treatments $(\mathrm{W})$, probably due to the higher impact of the contamination in a non-fertilised scenario.

The plant uptake and accumulation of $\mathrm{Cd}$ seem to be better described by the $\mathrm{Cd}$ DTPA extract than with the ammonium acetate extract. The former extraction technique could be recommended to evaluate $\mathrm{Cd}$ phytoavailability in calcareous soils. Several authors have found a positive correlation between phosphorus application as monoammonium phosphate and $\mathrm{Cd}$ accumulation in plants (Grant and Bailey, 1997), but we could not establish such a correlation.

\section{REFERENCES}

Beckett, P.H.T., 1989. The use of extractants in studies on trace metals in solis, sewage sludges and sludge-treated soils. Adv. Soil Sci. 9, 143-176.

Cabral, A.R., Lefebvre, G., 1998. Use of sequential extraction in the study of heavy metal retention by silty soils. Water Air Soil Pollut. 102, 329-344.

Chang, A.C., Page, A.L., Warneke, J.E., Grogurevic, E., 1984. Sequential extraction of soil heavy metals following a sludge application. J. Environ. Qual. 13, 33-38.

Förstner, U.W., Calmano, K., Conrad, H., Jarsch, H., Schimkus, C., Schoer, J., 1981. Chemical speciation of heavy metals in solid waste material (sewage sludge, mining wastes, dredged materials, polluted sediments) by sequential extraction . In: Proc. Int. Conf. Heavy Metal Environ. WHO/EED, 698-704.

Gerritse, R.G., Van Driel, W., Smilde, K.W., van Luit, B., 1983. Uptake of heavy metals by crops in relation to their concentration in the soil solution. Plant Soil 75, 393-404.

Grant,C.A, Bailey, L.D., 1997. Effects of phosphorus and zinc fertiliser management on cadmium accumulation in flaxseed. J. Sci. Food Agric. 73, 307-314.

Hanafi, M.M., Salwa, H., 1998. Cadmium and zinc in acid tropical soils: II. Influence of humic acid addition on soils properties and their adsorption. Commun. Soil Sci. Plant Anal. 29, 1933-1947.

He, Q.B., Singh, B.R., 1993. Effect of organic matter on the distribution, extractability and uptake of cadmium in soils. J. Soil Sci. 44, 641-650.

Iyengar, S.S., Martens, D.C., Miller, W.P., 1981. Distribution and plant availability of soil zinc fractions. Soil Sci. Soc. Am. J. 45, 735-739. 
Kalra Y.P., Maynard, D.G., Radford, F.G., 1988. Microwave digestion of tree foliage for multielement analysis. Can. J. Forest Res. 19, 981-985.

Kim, S.J., Chang, A.C., Page, A.L., Warneke, J.E., 1988. Relative concentrations of cadmium and zinc in tissue of selected food plants grown on sludge-treated soils. J. Environ. Qual. 17, 568-573.

White, R.T., Douthit, G.E., 1985. Use of microwave oven and nitric acid-hydrogen peroxide digestion to prepare botanical materials of elemental analysis by inductively coupled argon plasma emission spectroscopy. J. Assoc. Off. Anal. Chem. 68, 766-769.

Knudsen D., Peterson, G.A., Pratt, P.F., 1982. Lithium, sodium and potassium. In: ASASSSA (eds) Methods of Soil Analysis. Madison, pp 225-246

Legret, M., Divet, L., Juste, C., 1988. Movement and speciation of heavy metals in a soil amended with sewage sludge containing large amount of $\mathrm{Cd}$ and Ni. Water Res. 22, 953-959.

Liao, M., Huang, Ch., Xie, Zh., 1999. Effect of pH on transport and transformation of cadmium in soil-water system. Huanjing Kexue Xuebao, 19, 81-86.

Logan, T.J., Feltz, R.E., 1985. Plant uptake of cadmium from acid-extracted anaerobically digested sewage sludge. J. Environ. Qual. 14, 495-500.

Logan, T.J., Lindsay, B.J., Goins, L.E., Ryan, J.A. 1997. Field assessment of sludge metal bioavailability to crops: sludge rate response. J. Environ. Qual. 26, 534-550.

Moral, R., Navarro-Pedreño, J., Gomez, I., Mataix J. 1996. Quantitative analysis of organic residues: effects of sample preparation in the determination of metals. Commun. Soil Sci. Plant Anal. 27, 753-761

Moral, R., Gomez, I., Navarro-Pedreño, J., Mataix J., 1994. Effects of cadmium on nutrient distribution, yield, and growth of tomato grown in soilless culture. J. Plant Nutr., 17, 953-962.

Navarro Pedreño J., Gomez, I., Moral, R., Mataix, J., 1996. Improving the agricultural value of a semi-arid soil by addition of sewage sludge and almonds residue. Agric. Ecosyst. Environ. 58, 115-119

Raskin, I., Ensley, B.D., 2000. Phytoremediation of toxic metals. In: Using Plants to Clean up the Environment. John Wiley and Sons Inc. New York. 304 p.

Schalscha, E.G., Morales, M., Ahumada, Y., Schirado, T., Pratt, P.F., 1980. Fractionation of $\mathrm{Zn}, \mathrm{Cu}, \mathrm{Cr}$ and $\mathrm{Ni}$ in wastewater solids and in soil. Agrochimica 24, 361-368.

Shuman, L.M. 1991. Chemical forms of micronutrients in soils. In Micronutrients in Agriculture, J.J. Mortvedt et al (Eds). SSSA, Madison, WI, pp 113-144.

Singh, S.P., Tack, F.M., Verloo, M.G., 1998. Heavy metal fractionation and extractability in dredged sediment derived surface soils. Water Air Soil Pollut. 102, 313-328.

Soil Survey Staff, 1998. Keys to Soil Taxonomy, Eighth Edition. USDA. Washington.

Soon, Y.K., Bates, T.E., 1982. Chemical pools of Cd, Ni and $\mathrm{Zn}$ in polluted soils and some preliminary indications of their availability to plants. J.Soil Sci. 33, 477-488.

Tjell, J.C., Hansen, J.A.A., Christensen, T.H., Hovmand, M.F., 1981. Prediction of cadmium concentrations in danish soils. In: P.L. Hermite and H. Ott (eds.). Characterization, Treatment and Use of Sewage Sludge, D. Reidel Publ. Co., Dordrecht, Holland, 1981, pp 652-664.

Vigil de la Villa, R., de la Flor, M., Cala, V., 1997. Influence of carbonate on cadmium distribution in soils under semiarid environment. Agrochimica 41, 270-278.

White, R.T., Douthit, G.E., 1985. Use of microwave oven and nitric acid-hydrogen peroxide digestion to prepare botanical materials of elemental analysis by inductively coupled argon plasma emission spectroscopy. J. Assoc. Off. Anal. Chem. 68, 766-769. 
Wolterbeek, H. Th., van der Meer, A., de Bruin, M., 1988. The uptake and distribution of cadmium in tomato plants as affected by ethylenediaminetetracetic acid and 2,4dinitrophenol. Environ. Pollut. 55, 301-315. 
Table 1. Composition of the soil and sewage sludge used

\begin{tabular}{|c|c|c|}
\hline & Soil & sewage sludge \\
\hline Clay $(<0.002$ mm) $(\%)$ & 28 & -- \\
\hline Silt $\quad(0.05-0.002 \mathrm{~mm})(\%)$ & 30 & -- \\
\hline Sand $(2-0.05 \mathrm{~mm})(\%)$ & 42 & -- \\
\hline Total $\mathrm{CaCO}_{3}$ equivalent $(\%)$ & 62 & -- \\
\hline Active lime (\%) & 15.3 & -- \\
\hline pH $(1: 5)_{\text {water }}$ & 8.7 & 6.2 \\
\hline E.C. $(1: 5)_{\text {water }}(d S / m)$ & 0.45 & 5.51 \\
\hline Oxidable organic matter $\left(\mathrm{g} \mathrm{kg}^{-1}\right)$ & 24.5 & 570 \\
\hline N Kjeldahl $\left(\mathrm{g} \mathrm{kg}^{-1}\right)$ & 1.40 & 30.1 \\
\hline $\mathbf{P}\left(\mathbf{m g ~ k g} \mathbf{~}^{-1}\right)$ & 0.036 & 17.1 \\
\hline $\mathrm{K}\left(\mathrm{mg} \mathrm{kg}^{-1}\right)$ & 0.29 & 1.7 \\
\hline $\mathrm{Ca}\left(\mathrm{mg} \mathrm{kg}^{-1}\right)$ & 5.31 & 66 \\
\hline $\operatorname{Mg}\left(\mathrm{mg} \mathrm{kg}^{-1}\right)$ & 0.64 & 7.0 \\
\hline $\mathrm{Na}\left(\mathrm{mg} \mathrm{kg}^{-1}\right)$ & 0.53 & 0.04 \\
\hline $\mathrm{Fe}\left(\mathrm{mg} \mathrm{kg}^{-1}\right)$ & 1.8 & 2300 \\
\hline $\mathrm{Cu}\left(\mathrm{mg} \mathrm{kg}^{-1}\right)$ & 3.5 & 270 \\
\hline $\operatorname{Mn}\left(\mathrm{mg} \mathrm{kg}^{-1}\right)$ & 3.0 & 123 \\
\hline $\mathrm{Zn}\left(\mathrm{mg} \mathrm{kg}^{-1}\right)$ & 7.8 & 235 \\
\hline $\mathrm{Cd}\left(\mathrm{mg} \mathrm{kg}^{-1}\right)$ & $\mathrm{nd}^{\mathrm{a}}$ & 0.5 \\
\hline
\end{tabular}

${ }^{a}$ nd: Cd content under AAS-graphite furnace detection level. 
Table 2. Cd-Ammonium acetate and DTPA-Cd soil extracts (mg/kg d.w.) determined in the combined treatments (Fertilisation $(\mathrm{F}) \mathrm{x}$ Pollution $(\mathrm{P})$ )

\begin{tabular}{|c|c|c|c|c|c|c|}
\hline & \multicolumn{3}{|c|}{ Cd-Ammonium acetate extract } & \multicolumn{3}{|c|}{ Cd-DTPA extract } \\
\hline & S1 & S2 & $\mathbf{S 3}$ & S1 & $\mathbf{S 2}$ & S3 \\
\hline W/0 & nd & nd & nd & nd & nd & nd \\
\hline$W / 3$ & $0.2 \mathrm{a}$ & $0.3 \mathrm{a}$ & $0.3 \mathrm{a}$ & $1.5 \mathrm{a}$ & $0.7 \mathrm{a}$ & $1.0 \mathrm{a}$ \\
\hline $\mathrm{W} / \mathbf{3 0}$ & $4.6 \mathrm{~b}$ & $4.6 \mathrm{~b}$ & $3.6 \mathrm{~b}$ & $12.7 \mathrm{~b}$ & $8.5 \mathrm{~b}$ & $8.4 \mathrm{~b}$ \\
\hline W/100 & $14.7 \mathrm{c}$ & $15.7 \mathrm{c}$ & $12.8 \mathrm{c}$ & $18.8 \mathrm{c}$ & $24.2 \mathrm{c}$ & $22.0 \mathrm{c}$ \\
\hline F-Anova & $* * *$ & $* * *$ & $* * *$ & $* * *$ & $* * *$ & $* * *$ \\
\hline SS/0 & nd & nd & nd & nd & nd & nd \\
\hline $\mathrm{SS} / 3$ & $0.4 \mathrm{a}$ & $0.2 \mathrm{a}$ & $0.2 \mathrm{a}$ & $1.4 \mathrm{a}$ & 0.9 a & $1.0 \mathrm{a}$ \\
\hline SS/30 & $4.3 \mathrm{~b}$ & $3.9 \mathrm{~b}$ & $4.1 \mathrm{~b}$ & $14.4 \mathrm{~b}$ & $11.2 \mathrm{~b}$ & $11.5 \mathrm{~b}$ \\
\hline $\mathrm{SS} / \mathbf{1 0 0}$ & $17.1 \mathrm{c}$ & $15.6 \mathrm{c}$ & $14.5 \mathrm{c}$ & $19.7 \mathrm{c}$ & $23.7 \mathrm{c}$ & $28.7 \mathrm{c}$ \\
\hline F-Anova & $* * *$ & $* * *$ & $* * *$ & $* * *$ & $* * *$ & $* * *$ \\
\hline IN/0 & nd & nd & nd & nd & nd & nd \\
\hline IN/3 & $0.4 \mathrm{a}$ & $0.4 \mathrm{a}$ & $0.4 \mathrm{a}$ & $0.8 \quad \mathrm{a}$ & $0.8 \mathrm{a}$ & $1.0 \mathrm{a}$ \\
\hline IN/30 & $4.2 \mathrm{~b}$ & $4.1 \mathrm{~b}$ & $3.3 \mathrm{~b}$ & $11.8 \mathrm{~b}$ & $9.0 \mathrm{~b}$ & $8.1 \mathrm{~b}$ \\
\hline IN/100 & $15.0 \mathrm{c}$ & $16.4 \mathrm{c}$ & $10.3 \mathrm{c}$ & $19.3 \mathrm{c}$ & $22.3 \mathrm{c}$ & $21.1 \mathrm{c}$ \\
\hline F-Anova & $* * *$ & $* * *$ & $* * *$ & $* * *$ & $* * *$ & $* * *$ \\
\hline $\mathbf{F}$ & ns & $\mathrm{ns}$ & $* * *$ & $*$ & ns & $* * *$ \\
\hline $\mathbf{P}$ & $* * *$ & $* * *$ & $* * *$ & $* * *$ & $* * *$ & $* * *$ \\
\hline $\mathbf{F} \times \mathbf{P}$ & ns & $\mathrm{ns}$ & $* * *$ & $*$ & ns & $* * *$ \\
\hline
\end{tabular}

$*, * *$ and $* * *$ indicate significant differences at $\mathrm{p}=0.05,0.01,0.001$ respectively and $\mathrm{ns}=$ non significant. Figures within vertical columns followed by the same letter are not different statistically $(\mathrm{p}=0.05)$. 
Table 3. Cd content in stem and branches, leaf and tomato fruit $(\mathrm{mg} / \mathrm{kg})$ determined in the combined treatments (Fertilisation $(\mathrm{F}) \times$ Pollution $(\mathrm{P})$ )

\begin{tabular}{|c|c|c|c|c|c|c|c|c|}
\hline & \multicolumn{3}{|c|}{ Stem and branches } & \multicolumn{3}{|l|}{ Leaf } & \multicolumn{2}{|l|}{ Fruit } \\
\hline & S1 & $\mathbf{S 2}$ & S3 & S1 & $\mathbf{S 2}$ & S3 & $\mathbf{S 2}$ & S3 \\
\hline W/0 & nd & nd & nd & nd & nd & nd & nd & nd \\
\hline W/3 & $2.2 \mathrm{a}$ & $2.8 \mathrm{a}$ & 3.0 & $4.2 \mathrm{a}$ & $4.3 \mathrm{a}$ & $6,0 \mathrm{a}$ & $0.4 \mathrm{a}$ & $0.9 \mathrm{a}$ \\
\hline W/30 & $10.1 \mathrm{~b}$ & $10.5 b$ & 7.2 & $20.8 b$ & $20.4 b$ & $14,1 \mathrm{~b}$ & $1.4 \mathrm{~b}$ & $3.4 \mathrm{~b}$ \\
\hline W/100 & $15.2 \mathrm{c}$ & $15.9 \mathrm{c}$ & 14.8 & $42.2 \mathrm{c}$ & $29.9 \mathrm{c}$ & $28,8 \mathrm{c}$ & $4.6 \mathrm{c}$ & $4.6 \mathrm{c}$ \\
\hline F-Anova & $* * *$ & $* * *$ & $* * *$ & $* * *$ & $* * *$ & $* * *$ & $* * *$ & $* * *$ \\
\hline SS/0 & nd & nd & nd & nd & nd & nd & nd & nd \\
\hline SS/3 & $3.1 \mathrm{a}$ & $1.3 \mathrm{a}$ & 2.5 & $5.3 \mathrm{a}$ & $4.6 \mathrm{a}$ & $11,1 \mathrm{a}$ & $0.8 \mathrm{a}$ & $1.0 \mathrm{a}$ \\
\hline SS/30 & $8.7 \mathrm{~b}$ & $6.8 b$ & 12.5 & $16.7 \mathrm{~b}$ & $19.0 \mathrm{~b}$ & $22,0 \mathrm{~b}$ & $3.2 b$ & $5.3 b$ \\
\hline $\mathrm{SS} / \mathbf{1 0 0}$ & $15.4 \mathrm{c}$ & $15.0 \mathrm{c}$ & 24.6 & $33.1 \mathrm{c}$ & $39.0 \mathrm{c}$ & $69,5 c$ & $4.9 \mathrm{c}$ & $8.9 \mathrm{c}$ \\
\hline F-Anova & $* * *$ & $* * *$ & $* * *$ & $* * *$ & $* * *$ & $* * *$ & $* * *$ & $* * *$ \\
\hline IN/0 & nd & nd & nd & nd & nd & nd & nd & nd \\
\hline IN/3 & $3.1 \mathrm{a}$ & $2.2 \mathrm{a}$ & 3.0 & $8.1 \mathrm{a}$ & $3.3 \mathrm{a}$ & $6,0 \mathrm{a}$ & $0.6 \mathrm{a}$ & $0.7 \mathrm{a}$ \\
\hline IN/30 & $6.6 \mathrm{~b}$ & $4.9 \mathrm{~b}$ & 5.8 & $13.3 \mathrm{~b}$ & $8.7 \mathrm{~b}$ & $10,0 \mathrm{~b}$ & $1.6 \mathrm{~b}$ & $2.3 \mathrm{~b}$ \\
\hline IN/100 & $9.4 \mathrm{c}$ & $6.6 \mathrm{c}$ & 10.9 & $21.2 \mathrm{c}$ & $20.1 \mathrm{c}$ & $28,9 \mathrm{c}$ & $3.2 \mathrm{c}$ & $5.2 \mathrm{c}$ \\
\hline F-Anova & $* * *$ & $* * *$ & $* * *$ & $* * *$ & $* * *$ & $* * *$ & $* * *$ & $* * *$ \\
\hline $\mathbf{F}$ & $* * *$ & $* * *$ & $* * *$ & $* * *$ & $* * *$ & $* * *$ & $* * *$ & $* * *$ \\
\hline $\mathbf{P}$ & $* * *$ & $* * *$ & $* * *$ & $* * *$ & $* * *$ & $* * *$ & $* * *$ & $* * *$ \\
\hline $\mathbf{F} \times \mathbf{P}$ & $* * *$ & $* * *$ & $* * *$ & $* * *$ & $* * *$ & $* * *$ & $* * *$ & $* * *$ \\
\hline
\end{tabular}

$*, * *$ and $* * *$ indicate significant differences at $\mathrm{p}=0.05,0.01,0.001$ respectively and $\mathrm{ns}=$ non significant. Figures within vertical columns followed by the same letter are not different statistically $(\mathrm{p}=0.05)$. 
Table 4. Aerial biomass production and yield in the combined treatments (Fertilisation (F) x Pollution (P)).

\begin{tabular}{|c|c|c|c|c|}
\hline & \multicolumn{3}{|c|}{ Aerial biomass (g/plant d.w.) } & \multirow{2}{*}{$\frac{\text { Yield }}{\text { (g/plant f.w.) }}$} \\
\hline & S1 & $\mathbf{S 2}$ & $\mathbf{S 3}$ & \\
\hline W/0 & $8,3 \mathrm{ab}$ & $26,0 \mathrm{a}$ & $24,8 \mathrm{a}$ & $459 \mathrm{a}$ \\
\hline $\mathbf{W} / \mathbf{3}$ & $10,8 \mathrm{c}$ & $14,8 \mathrm{~b}$ & $11,8 b$ & $429 a$ \\
\hline W/30 & $9,3 \mathrm{a}$ & $12,0 \mathrm{c}$ & $14,5 b$ & $411 \mathrm{a}$ \\
\hline W/100 & $7,7 \mathrm{~b}$ & $17,3 b$ & $25,5 \mathrm{a}$ & $336 b$ \\
\hline F-Anova & $* *$ & $* * *$ & $* * *$ & $*$ \\
\hline SS/0 & $23,0 \mathrm{a}$ & $47,0 \mathrm{a}$ & $48,7 \mathrm{a}$ & $1035 \mathrm{a}$ \\
\hline $\mathrm{SS} / \mathbf{3}$ & $22,0 \mathrm{a}$ & $42,3 b$ & $45,8 \mathrm{a}$ & $1089 a$ \\
\hline SS/30 & $22,5 \mathrm{a}$ & $43,0 \mathrm{~b}$ & $48,5 \mathrm{a}$ & $960 \mathrm{a}$ \\
\hline SS/100 & $18,5 b$ & $47,5 \mathrm{a}$ & $39,0 \mathrm{~b}$ & $972 \mathrm{a}$ \\
\hline F-Anova & $*$ & $* *$ & $* * *$ & ns \\
\hline IN/0 & $24,0 \mathrm{a}$ & $54,1 \mathrm{ab}$ & $44,6 \mathrm{a}$ & $711 \mathrm{ab}$ \\
\hline IN/3 & $25,1 \mathrm{a}$ & $59,3 \mathrm{a}$ & $39,5 b$ & $639 \mathrm{a}$ \\
\hline IN/30 & $19,2 b$ & $49,8 b$ & $36,5 \mathrm{c}$ & $606 a$ \\
\hline IN/100 & $21,3 a b$ & $45,0 \mathrm{c}$ & $40,5 b$ & $801 \mathrm{~b}$ \\
\hline F-Anova & $*$ & $* *$ & $* *$ & $*$ \\
\hline $\mathbf{F}$ & $* * *$ & $* * *$ & $* * *$ & $* * *$ \\
\hline $\mathbf{P}$ & $* *$ & $* *$ & $* * *$ & ns \\
\hline $\mathbf{F} \times \mathbf{P}$ & $* * *$ & $* * *$ & $* * *$ & $* *$ \\
\hline
\end{tabular}

$* * *$ and $* * *$ indicate significant differences at $\mathrm{p}=0.05,0.01,0.001$ respectively and $n s=$ non significant. Figures within vertical columns followed by the same letter are not different statistically $(\mathrm{p}=0.05)$. 
Table 5. Linear correlation between the different $\mathrm{Cd}$ soil pools and $\mathrm{Cd}$ in plant parts.

\begin{tabular}{|c|c|c|c|c|}
\hline \multirow[b]{2}{*}{ Cd soil pool } & & \multicolumn{3}{|l|}{ Cd in plant } \\
\hline & & Stem + branches & leaf & fruit \\
\hline \multirow[t]{3}{*}{ Cd added } & $\mathrm{W}$ & $\begin{array}{l}0.141 \mathrm{Cd}+2.172 \\
\mathrm{r}=0.932\end{array}$ & $\begin{array}{l}0.321 \mathrm{Cd}+3.872 \\
\mathrm{r}=0.958\end{array}$ & $\begin{array}{l}0.043 \mathrm{Cd}+0.151 \\
\mathrm{r}=0.997\end{array}$ \\
\hline & SS & $\begin{array}{l}0.165 \mathrm{Cd}+1.741 \\
\mathrm{r}=0.956\end{array}$ & $\begin{array}{l}0.424 C d+3.674 \\
r=0.981\end{array}$ & $\begin{array}{l}0.046 \mathrm{Cd}+0.897 \\
\mathrm{r}=0.945\end{array}$ \\
\hline & IN & $\begin{array}{l}0.081 \mathrm{Cd}+1.845 \\
\mathrm{r}=0.897\end{array}$ & $\begin{array}{l}0.211 \mathrm{Cd}+2.787 \\
\mathrm{r}=0.922\end{array}$ & $\begin{array}{l}0.036 \mathrm{Cd}+0.391 \\
\mathrm{r}=0.979\end{array}$ \\
\hline \multirow[t]{3}{*}{$\begin{array}{l}\mathrm{Cd} \text { in } \mathrm{NH}_{4} \mathrm{AcO} \\
\text { extract }\end{array}$} & $\mathrm{W}$ & $\begin{array}{l}0.984 \mathrm{Cd}+2.233 \\
\mathrm{r}=0.940\end{array}$ & $\begin{array}{l}2.256 \mathrm{Cd}+3.897 \\
\mathrm{r}=0.966\end{array}$ & $\begin{array}{l}0.301 \mathrm{Cd}+0.159 \\
\mathrm{r}=0.922\end{array}$ \\
\hline & SS & $\begin{array}{l}1.233 \mathrm{Cd}+2.055 \\
\mathrm{r}=0.967\end{array}$ & $\begin{array}{l}2.899 \mathrm{Cd}+4.564 \\
\mathrm{r}=0.978\end{array}$ & $\begin{array}{l}0.421 \mathrm{Cd}+0.958 \\
\mathrm{r}=0.934\end{array}$ \\
\hline & IN & $\begin{array}{l}0.623 \mathrm{Cd}+2.012 \\
\mathrm{r}=0.911\end{array}$ & $\begin{array}{l}1.876 \mathrm{Cd}+2.452 \\
\mathrm{r}=0.942\end{array}$ & $\begin{array}{l}0.316 \mathrm{Cd}+0.397 \\
\mathrm{r}=0.978\end{array}$ \\
\hline \multirow[t]{3}{*}{$\begin{array}{l}\text { Cd in DTPA } \\
\text { extract }\end{array}$} & $\mathrm{W}$ & $\begin{array}{l}0.677 \mathrm{Cd}+1.264 \\
\mathrm{r}=0.987\end{array}$ & $\begin{array}{l}1.454 C d+3.018 \\
r=0.967\end{array}$ & $\begin{array}{l}0.189 \mathrm{Cd}+0.256 \\
\mathrm{r}=0.955\end{array}$ \\
\hline & SS & $\begin{array}{l}0.725 \mathrm{Cd}+0.752 \\
\mathrm{r}=0.989\end{array}$ & $\begin{array}{l}1.897 \mathrm{Cd}+1.897 \\
\mathrm{r}=0.988\end{array}$ & $\begin{array}{l}0.254 \mathrm{Cd}+0.597 \\
\mathrm{r}=0.975\end{array}$ \\
\hline & IN & $\begin{array}{l}0.389 \mathrm{Cd}+1.387 \\
\mathrm{r}=0.954\end{array}$ & $\begin{array}{l}0.978 \mathrm{Cd}+2.124 \\
\mathrm{r}=966\end{array}$ & $\begin{array}{l}0.189 \mathrm{Cd}+0.265 \\
\mathrm{r}=0.995\end{array}$ \\
\hline
\end{tabular}

